\title{
Performance of herbicides in sugarcane straw
}

\author{
Dinâmica de herbicidas em palha de cana-de-açúcar
}

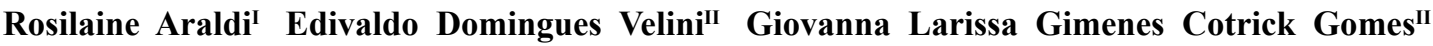 Leandro TropaldiII Ilca Puertas de Freitas e SilvaII Caio Antonio CarbonariII}

\section{ABSTRACT}

The process of mechanical harvesting of sugarcane generates a large deposition of straw on the soil surface, providing a coverage that several studies have found important for reducing the weed population. Although such coverage reduces weed infestations, additional management, including chemical control, is still needed. Thus, this study aimed to evaluate the leaching of atrazine, pendimethalin, metribuzin, clomazone, diuron and hexazinone in sugarcane straw. The experiment was conducted at the School of Agronomic Engineering at UNESP (Universidade Estadual Paulista) - Botucatu/SP. The sugarcane straw was collected in the field, cut and placed in quantities of $10 \mathrm{t} \mathrm{ha} \mathrm{h}^{-1}$ in the capsules used as experimental units. The experimental design was completely randomized, using six herbicide treatments and four replications. Within 24 hours after the herbicides were applied in capsules with straw, five different rainfalls $(5,10,20,50$ and $100 \mathrm{~mm})$ were simulated. The leached water was collected for chromatographic analysis. The herbicide percentages that crossed the straw layer were statistically correlated with the rainfall amount by the Mitscherlich model that compares the facility of herbicide removal from sugarcane straw. In summary, pendimethalin did not present quantified transposition of the product by sugarcane straw even with a rain simulation of $100 \mathrm{~mm}$. Furthermore, two different profiles of facility to transpose the herbicides in straw were found: one for metribuzin and hexazinone that crossed quickly through the straw layer and another for atrazine, diuron and clomazone that required more rainfall to be leached from coverage to the soil according to the maximum removable amount of each herbicide.

Key words: atrazine, pendimethalin, metribuzin, clomazone, diuron, hexazinone.

RESUMO

O processo de colheita mecanizada de cana-de-açúcar gera uma grande quantidade de palhada depositada na superficie do solo e vários trabalhos destacam a importância da manutenção dessas coberturas em sistemas de cana crua, com destaque na redução da população de plantas daninhas. Mas, apesar de a cobertura vegetal reduzir a infestação das plantas daninhas, medidas complementares, como o controle químico, ainda são necessárias. Dessa forma, o objetivo deste estudo foi avaliar a transposição dos herbicidas atrazine, pendimethalin, metribuzin, clomazone, diuron e hexazinone em palha de cana-de-açúcar. $O$ experimento foi desenvolvido na Faculdade de Ciências Agronomicas da UNESP - Botucatu/SP. A palha da cana-de-açúcar foi coletada em campo, cortada e colocada em quantidades de $10 \mathrm{t} \mathrm{ha} \mathrm{h}^{-1}$ em recipientes plásticos utilizados como unidades experimentais. $O$ delineamento experimental foi inteiramente casualisado, eforam testados seis tratamentos (atrazine, pendimethalin, metribuzin, clomazone, diuron e hexazinone) e quatro repetições. Nas cápsulas com palha e pulverizadas, foi realizado, no periodo de 24 horas após a aplicação, a simulação de diferentes lâminas de chuva (5, 10, 20, 50 e 100mm) e coletada a água lixiviada para posterior quantificação cromatográfica. Como análise estatística, os herbicidas foram correlacionados com as lâminas de chuva e foi usado o modelo de Mitscherlich para ajuste dos dados, que permitiu comparar a facilidade de remoção dos herbicidas pela palha. Em sintese, para o pendimethalin, não se observou transposição quantificada do produto pela palha de cana-de-açúcar, mesmo com uma lâmina de $100 \mathrm{~mm}$ de chuva. Foram encontrados dois perfis diferentes de facilidade de transposição dos herbicidas em palha: um para o metribuzin e hexazinone, que passaram rapidamente pela camada de palha, e outro para atrazine, clomazone e diuron, que precisaram de uma quantidade superior de chuva para serem lixiviados da cobertura vegetal, em função da quantidade máxima removivel dos herbicidas.

Palavras-chave: atrazine, pendimethalin, metribuzin, clomazone, diuron, hexazinone.

\section{INTRODUCTION}

Sugarcane (Saccharum spp.), a great source of energy for humans, is produced between

ILaboratório Nacional de Ciência e Tecnologia do Bioetanol (CTBE), 13083-100, Campinas, SP, Brasil. E-mail: rosilainearaldi@hotmail.com. Corresponding author.

IDepartamento de Produção e Melhoramento Vegetal, Faculdade de Ciências Agronômicas (FCA), Universidade Estadual Paulista "Júlio de Mesquita Filho" (UNESP), Botucatu, SP, Brasil. 
latitudes of $36.7^{\circ}$ north and $31.0^{\circ}$ south of the equator, covering areas of the tropical and subtropical zone, ranging from sea level to $1000 \mathrm{~m}$ altitude. Worldwide, sugarcane is produced in an area of 26.42 million hectares (FAOSTAT, 2013). Sugarcane production problems include the presence of weeds, responsible for up to $80 \%$ of production losses (AZANIA et al., 2008). This infestation by weeds is a major biotic factor in sugarcane agroecosystem that has the ability to interfere in the development and productivity of the culture with reductions in the quantity and quality of the harvested product, with reductions in the number of viable cuts, rises in production cost and impairment of the harvesting and transportation of sugarcane (KUVA et al., 2003).

There are about 1,000 weed species stimated that inhabit the sugarcane agroecosystems, distributed among the different producing regions of the world (CARVALHO et al., 2005). This weed infestation in sugarcane is highly specific, and the implementation of mechanized harvesting has changed the type of weeds in the community (AZANIA et al., 2002). Therefore, several studies have been developed aiming to elucidate the behavior of these plants and thus manage them satisfactorily with control practices that reach producers.

In a study of different weed management systems in sugarcane in the U.S. state of Louisiana, JUDICE et al. (2007) found that the average of winter weeds covering the ground in March was only $7 \%$ where the crop straw had not been not removed, compared to $14 \%$ in areas where straw had been burned and $17 \%$ where the straw had been mechanically removed. Furthermore, other researches show the importance of maintaining the straw on the soil surface in sugarcane systems, and some studies have proven the effectiveness of the residue in reducing weed populations (AZANIA et al., 2002).

Straw coverage interferes in the dormancy, germination and death rate of weed seeds, promoting changes in the weed community. However, such modifications are very specific and dynamic since they depend on the type and amount of straw and especially on the weed species. In this manner, the level of weed suppression is directly related to the amount of residue left on the soil surface (CRUTCHFIELD et al., 1986). But currently, some biotypes of grasses are already displaying selectivity for and adaptation to the physical barrier of the straw, decreasing the previously presented suppression.

Although vegetal coverage reduces the competition from weeds, additional measures, such as chemical control, are still needed (YENISH et al.,
1996). In turn, the maintenance of straw on the soil surface can hinder the effectiveness of the herbicides applied in pre-emergence, because in this system the transport of the herbicide to the soil surface is done primarily by rainfall or irrigation, (MACIEL \& VELINI, 2005). This downward movement of herbicides from straw to soil, denominated leaching, is related primarily to solubility, type of herbicide formulation and the amount of straw.

Despite the advances in research on sugarcane cultivation, it still necessary to devote efforts to elucidate the behavior of pre-emergent herbicides in straw, particularly in relation to the dynamics of these products in the sugarcane system harvested without burning. Therefore, this study aimed to evaluate the leaching of atrazine, pendimethalin, metribuzin, clomazone, diuron and hexazinone through $10 \mathrm{tha}^{-1}$ of sugarcane straw.

\section{MATERIAL AND METHODS}

The experiment was performed in the Center for Advanced Research in Weeds Science (NUPAM) at the Universidade Estadual Paulista (UNESP) campus in Botucatu, São Paulo State. The study was conducted using the modified methodology (CORRÊA et al., 2006; NEGRISOLI et al., 2011; ROSSI et al., 2013) and replacing PVC experimental units with small plastic pots (capsules).

Sugarcane straw was collected in field, cut into small pieces and added in a known amount into the capsules. The weight of $1.75 \mathrm{~g}$ was added to each unit, corresponding to $10 \mathrm{tha}^{-1}$, which normally is left on soil surface after the sugarcane harvest and observed under field conditions. This amount was defined based by calculating the capsule area $\left(0.00159 \mathrm{~m}^{2}\right)$ for filling with exact amount of straw. Sugarcane straw moisture was around $15 \%$ in the installation moment.

Experimental design was randomized using six herbicidal treatments and four replications. The studied herbicides were: atrazine $(2.25 \mathrm{~kg}$ i.a ha-1), pendimethalin $(2.31 \mathrm{~kg}$ i.a ha-1), metribuzin $(1.27 \mathrm{~kg}$ i.a ha-1 $)$, clomazone $(1.05 \mathrm{~kg}$ i.a ha-1 $)$, diuron $\left(2.80 \mathrm{~kg} \mathrm{i}^{\mathrm{a} \mathrm{ha}}{ }^{-1}\right)$ and hexazinone $\left(0.56 \mathrm{~kg} \mathrm{i}^{\mathrm{a} \mathrm{h} \mathrm{ha}}{ }^{-1}\right)$.

Herbicide application was made by a stationary sprayer equipped with a spray bar constituted by four tips (XR 110.02), spaced $0.5 \mathrm{~m}$ apart and positioned at a height of $0.5 \mathrm{~m}$ above the capsules. For herbicide application, the system was operated at a displacement speed of $1 \mathrm{~m} \mathrm{~s}^{-1}$, corresponding to 45.0 Hertz in the frequency modulator, with spray consumption of $200 \mathrm{~L} \mathrm{ha}^{-1}$. A 
constant pressure of $1.5 \mathrm{bar}$, was applied by means of compressed air. The same equipment was used for rain simulation. Temperature and relative humidity conditions at the application moment were $18.1^{\circ} \mathrm{C}$ and $59 \%$ respectively.

Plates with known amounts of soil $(14.5 \mathrm{~g})$ were utilized as a target for detecting how much herbicide actually reached the sugarcane straw in the capsules. Herbicide was extracted by a method already developed and validated. In the total, there were 24 soil samples, including six herbicides and four replications.

In the capsules with pulverized straw, the different rain simulations $(5,10,20,50$ and $100 \mathrm{~mm}$ ) were performed within 24 hours after application. Rain was simulated cumulatively. In each simulation, the leached water was collected in receptacles, then measured and frozen for subsequent chromatographic quantification.

The studied herbicides were quantified by High Performance Liquid Chromatography (HPLCMS/MS), Shimadzu, model Proeminence UFLC, which combines 37 fast analyses and is an excellent separation performance, with high reliability of the results. The equipment has two LC-20AD pumps, SIL-20AC autoinjector, DGU-20A5 degasser, CBM$20 \mathrm{~A}$ controller system and CTO-20AC oven. The mass spectrometer 3200 Q TRAP (Applied Biosystems) is coupled to HPLC.

The fragment used for quantification of each compound was always the first of each compound. Detection and separation of the compounds were performed in a run and the retention times of compounds retained by the chromatography column were: atrazine $(6.47 \mathrm{~min})$, pendimethalin $(8.65 \mathrm{~min})$, metribuzin $(6.31 \mathrm{~min})$, clomazone $(6.55 \mathrm{~min})$, diuron $(6.5 \mathrm{~min})$ and hexazinone $(6.35 \mathrm{~min})$.

For the statistical analysis, the data on the herbicides (extracted maximum amount) that crossed the straw layer were correlated with the amount of rain. The generated regression of the correlations was analyzed via the program Sigma Plot, version 11, using the Mitscherlich model with two parameters: $y=a^{*}\left(1-10^{\left(-\mathrm{c}^{*} \mathrm{x}\right)}\right)$, where: $y=$ total amount of herbicide extracted (\%) from straw layer to soil surface; $a=$ maximum amount of herbicide leached through the straw, "a" $=100 ; c=$ the concavity of the curve and $x=$ amount of water necessary to move herbicide into the soil (mm). The procedure allows comparison of the facility with which the herbicides were removed from the sugarcane straw by the rainfall.

Based on the original model, the total amount extracted can be a function of the rainfall; an alternative applicable model calculates the rain simulation that promotes the leached percentage (relative to the extracted maximum) pre-established. In the latter case, the equation used to determine which rain blade $(\mathrm{x})$ to leach $(\% \mathrm{~L}) 50$ and $90 \%$ (Table 1) from the extracted maximum amount was: $x=\frac{2-\log (100-\% L)}{c}$

\section{RESULTS AND DISCUSSION}

Figure 1 provides a general representation for atrazine, metribuzin, clomazone, diuron and hexazinone evaluated in the experiment, presented as the percentage of the maximum amount of each herbicide extracted in relation to the rain simulations carried out at 24 hours after application. The regression coefficients adjusted for each herbicide are shown in table 1.

It should be emphasized that there were no traces of pendimethalin herbicide detected in the samples, even under the largest rainfall amount $(100 \mathrm{~mm})$. Herbicide abscence in the leached solution from sugarcane straw is justified by the product characteristics such as low solubility $\left(0.275 \mathrm{mg} \mathrm{L}^{-1}\right)$

Table 1 - Description of estimated regression equations obtained by Mitscherlich model (Figure 1) for the relation between extracted maximum amount $(\%)$ of herbicides in sugarcane straw as a function of different rainfall amounts, and the rainfall amount required to leach 50 and $90 \%$ of the herbicides. Botucatu/SP, 2014

\begin{tabular}{|c|c|c|c|c|c|c|}
\hline Coefficients & Atrazine & Pendimethalin & Metribuzin & Clomazone & Diuron & Hexazinone \\
\hline $\mathrm{a}$ & 100 & - & 100 & 100 & 100 & 100 \\
\hline $\mathrm{c}$ & 0.0236 & - & 0.0749 & 0.0286 & 0.0428 & 0.0558 \\
\hline $\mathrm{R}^{2}$ & 0.99 & - & 0.99 & 0.98 & 0.98 & 0.99 \\
\hline \multicolumn{7}{|l|}{ Leaching } \\
\hline $50 \%$ & 12.75 & - & 4.02 & 10.52 & 7.03 & 5.39 \\
\hline $90 \%$ & 42.37 & - & 13.35 & 34.96 & 23.36 & 17.92 \\
\hline
\end{tabular}



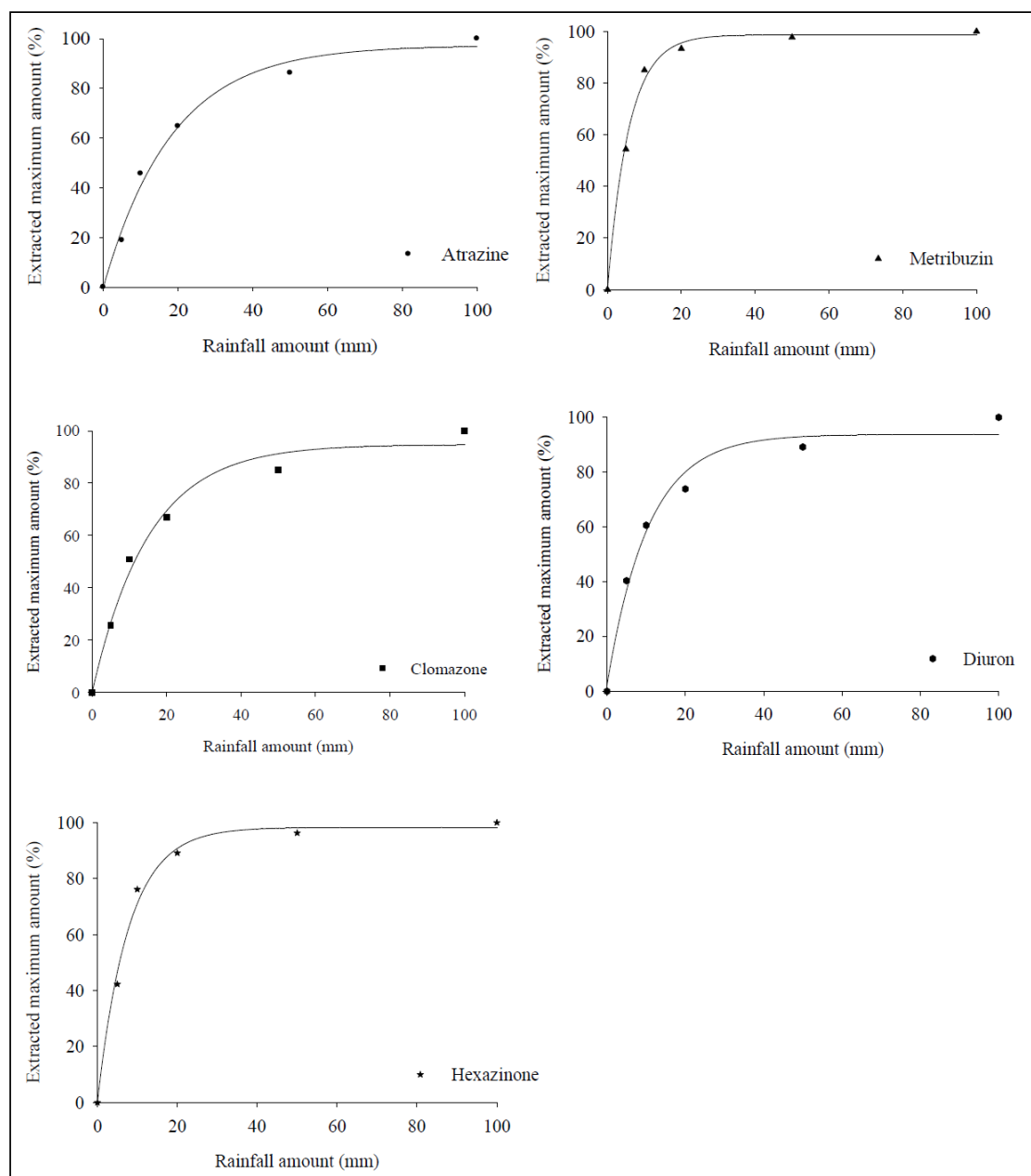

Figure 1 - Adjusted data by Mitscherlich model for extracted maximum percentage of the herbicides atrazine, metribuzin, clomazone, diuron and hexazinone in sugarcane straw $\left(10 \mathrm{t} \mathrm{ha}^{-1}\right)$ after different rain simulations $(\mathrm{mm})$. Botucatu/SP, 2014.

and high $\operatorname{Koc}\left(24,300 \mathrm{~g} \mathrm{~mL}^{-1}\right)$ (RODRIGUES \& ALMEIDA, 2011).

Given the difficulty of leaching the products from the straw, WAUCHOPE et al. (1992) reported that the average adsorption of pendimethalin was $5000 \mathrm{~mL} \mathrm{~g}^{-1}$, while the atrazine value was approximately $100 \mathrm{~mL} \mathrm{~g} \mathrm{~g}^{-1}$, in other words, a capacity 50 times higher than that of pendimethalin absorption. Thus, this greater retention capacity is well manifested by low concentration of the pendimethalin extracted from sugarcane straw in the current study.

Another herbicide that presents difficulty to transpose from the sugarcane straw to the soil is trifluralin. This product was not detected in the soil under mulch conditions, even after a rainfall of $20 \mathrm{~mm}$ applied 24 hours after application of the product on the field, unlike what was observed with atrazine in the study of RODRIGUES et al. (1997).

The best profile for leaching the herbicides by $10 \mathrm{t} \mathrm{ha} \mathrm{h}^{-1}$ of sugarcane straw was presented by metribuzin and hexazinone, which were shown to cross the straw more easily (Figure 2). Leaching $50 \%$ of the metribuzin and hexazinone required, respectively, 4 and $5 \mathrm{~mm}$ of rainfall in relation to extracted maximum. Furthermore, rain simulations of 13 and $18 \mathrm{~mm}$ were needed to move $90 \%$ of the respective metribuzin and hexazinone to the soil (Table 1).

Metribuzin was shown to be easily extractable by the straw under different rain simulations at 24 hours after application in the area. For the same purpose, ROSSI et al. (2013), verified that each one millimeter rise in simulated rain under 


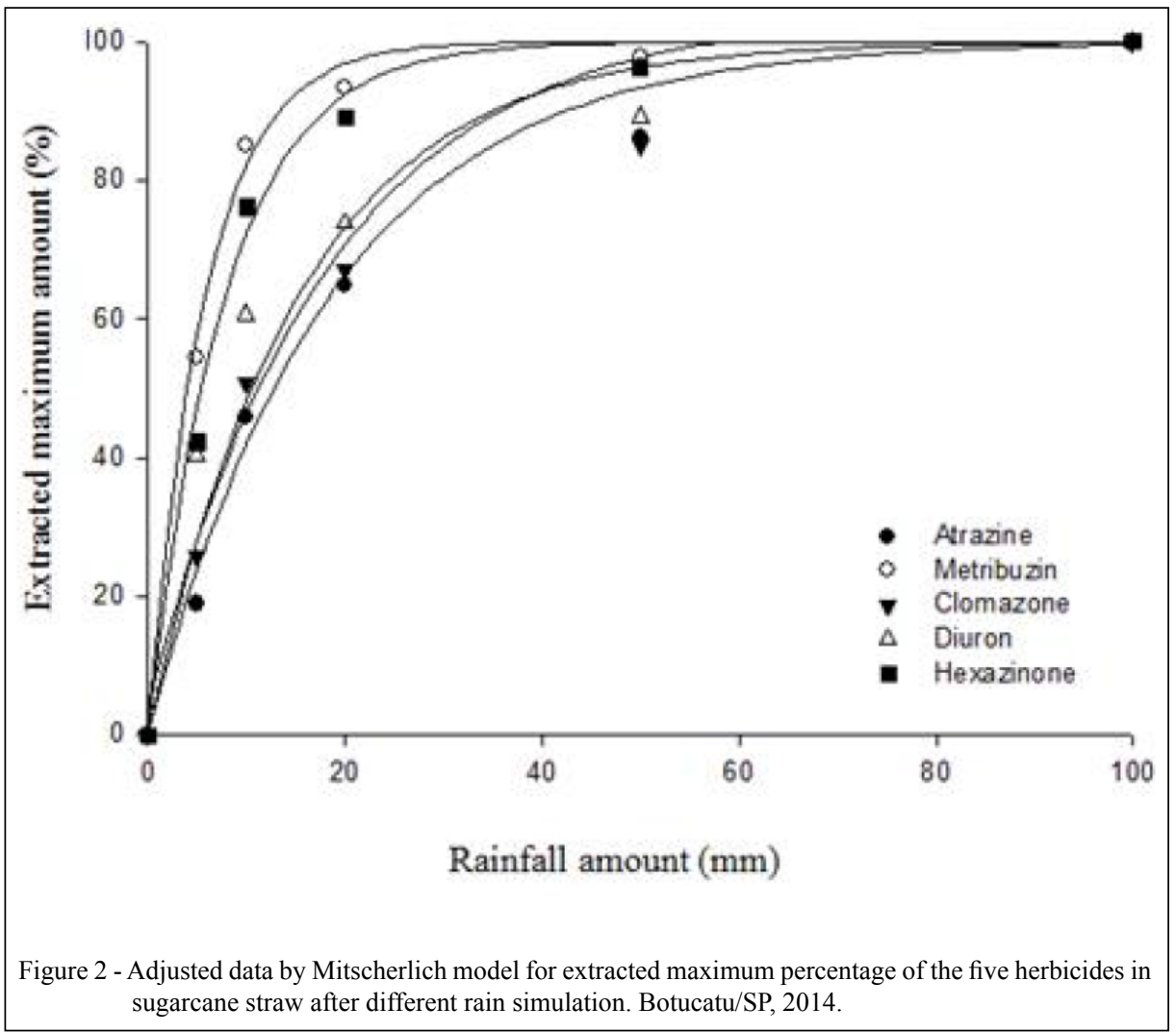

a treatment of $10 \mathrm{tha}^{-1}$ produced an increase in the herbicide extraction rate from sugarcane straw for, according to the model applied, more than $99 \%$ of metribuzin was extracted when rain reached $22 \mathrm{~mm}$, thereby demonstrating the effectiveness of this herbicide at transposing sugarcane straw.

Also for the formulated mixture of the herbicides hexazinone and diuron, CORREA et al. (2006) observed a leaching of $68 \%$ for hexazinone and $57 \%$ for diuron when measured 24 hours after application of $50 \mathrm{~mm}$ of rainfall. Thus, after the herbicide application, the amount and time of rainfall or irrigation are important factors that determine leaching of herbicides in sugarcane straw (CORRÊA et al., 2006).

For a second group of herbicides, leaching facility in sugarcane straw was found for atrazine, clomazone and diuron, which required a higher amount of rainfall to extract almost all herbicide from the vegetation coverage according to the removable maximum amount (Figure 1, 2 and Table 1). To achieve a $90 \%$ transposition of atrazine, clomazone and diuron, respective rainfalls of 42,35 and $23 \mathrm{~mm}$ were required.
This affinity of the compound for the straw can be justified by the adsorption coefficient of herbicides, which for atrazine was $15.9 \mathrm{~g} \mathrm{~mL}^{-1}$ at 24 hours after application in sugarcane residues, while that of metribuzin was $11.2 \mathrm{~g} \mathrm{~mL}^{-1}$ (SELIM et al., 2003), thus facilitating the extraction of the last herbicide by straw as detected in this experiment.

Assessing atrazine (Figure 1), it can be noted that rain simulations of 13 and $42 \mathrm{~mm}$ produced respective transpositions of 50 and $90 \%$ of the herbicide relative to the extractable maximum by sugarcane straw at 24 hours after application. TOFOLI et al. (2002), employing the active ingredient atrazine on sugarcane straw of $10 \mathrm{tha}^{-1}$ and simulation of different rainfall amounts, found that $92 \%$ of the atrazine crossed the straw under $65 \mathrm{~mm}$ of rainfall.

Clomazone produced transpositions of 50 and $90 \%$, relative to the extracted maximum, respectively, for simulated rains of 10 to $35 \mathrm{~mm}$ in $10 \mathrm{t}$ $\mathrm{ha}^{-1}$ of straw (Table 1). Applying the combination of clomazone and hexazinone (solubility $=1,100$ and $33,000 \mathrm{mg} \mathrm{L}^{-1}$ respectively) NEGRISOLI et al. (2011) noted that $2.5 \mathrm{~mm}$ of rainfall was sufficient to rinse the mixture of the sugarcane straw in the amount of 
5.0t $\mathrm{ha}^{-1}$. These results indicate that herbicides with high solubility can be retained by the straw layer and, depending on the solubility of the molecule, only a small amount of rainfall or irrigation is required to leach the herbicide from the straw toward the soil surface.

The adjusted data for the transposition of the herbicide diuron through the sugarcane straw layer when subjected to simulated rainfall of 7 or $23 \mathrm{~mm}$ at 24 hours after application were 50 and $90 \%$, respectively, in relation to the extractable maximum. NEGRISOLI et. al. (2002) also found highly similar values when evaluating the deposition and transport of diuron in sugarcane straw with precipitation 24 hours after the application.

These data on the leaching of herbicides in straw are extremely important and may be generally useful for understanding the behavior of some herbicides in a new system of sugarcane production, assisting in making some important decisions about the management of weeds in sugarcane culture.

\section{CONCLUSION}

Under the experimental conditions employed herein, it can be concluded that pendimethalin did not show transposition in $10 \mathrm{t}$ $\mathrm{ha}^{-1}$ sugarcane straw even after receiving $100 \mathrm{~mm}$ of simulated rain. Two distinct herbicide transposition profiles were found to be dependent on the maximum removable amount: one for metribuzin and hexazinone that crossed quickly through straw layer and another for atrazine, diuron and clomazone that required a higher amount of rainfall to be leached from the coverage straw.

\section{ACKNOWLEDGEMENT}

This research was supported by the Coordenação de Aperfeiçoamento de Pessoal de Nível Superior (CAPES) scholarship in my $\mathrm{PhD}$ research.

\section{REFERENCES}

AZANIA, A.A.P.M. et al. Interferência da palha de cana-de-açúcar (Saccharum spp.) na emergência de espécies de plantas daninhas da família Convolvulaceae. Planta Daninha, v.20, n.2, p.207212, 2002. Available from: <http://dx.doi.org/10.1590/S010083582002000200006>. Accessed: Feb. 14, 2014. doi: 10.1590/ S0100-83582002000200006.

AZANIA, C.A.M.; et al. Plantas daninhas. In: DINARDOMIRANDA, L.L. et al. (Ed.). Cana-de-açúcar. Campinas: Instituto Agronômico, 2008. p.465-490.

CARVALHO, S.J.P. et al. Curvas de dose-resposta para avaliação do controle de fluxos de emergência de plantas daninhas pelo herbicida imazapic. Planta Daninha, v.23, p.535542, 2005. Available from: < http://dx.doi.org/10.1590/S010083582005000300018>. Accessed: Feb. 14, 2014. doi: 10.1590/ S0100-83582005000300018.

CORRÊA, M.R. et al. Eficiência do herbicida diuron + hexazinone no controle de plantas daninhas na cultura de cana-de-açúcar em aplicações em pré e pós-emergência. In: CONGRESSO BRASILEIRO DA CIÊNCIA DAS PLANTAS DANINHAS, 25., 2006, Brasília, DF. Anais... Brasília: SBCPD; UNB; Embrapa Cerrados, 2006. p.364.

CRUTCHFIELD, D.A. et al. Effect of winter wheat (Triticum aestivum L.) straw mulch level on weed control. Weed Science, v.34, p.110-114, 1986. Available from: <http://www.jstor.org/ discover/10.2307/4044181>. Accessed: Mar. 22, 2014 doi: $10.2307 / 4044181$

FAOSTAT (FOOD AND AGRICULTURE ORGANIZATION OF THE UNITED NATIONS). Available from: <http://faostat. fao.org/site/567/DesktopDefault.aspx?PageID=567\#ancor $>$. Accessed: Mar. 10, 2014.

JUDICE, W.E. et al. Effects of crop residue management and tillage on weed control and sugarcane production. Weed Technology, v.21, p.606-611, 2007. Available from: $<$ http://www. jstor.org/discover/10.2307/4495905>. Accessed: Mar. 22, 2014. doi: 10.1614/WT-06-172.1.

KUVA, M.A. et al. Períodos de interferência das plantas daninhas na cultura da cana-de-açúcar. III - Capim-braquiária (Brachiaria decumbens) e capim-colonião (Brachiaria decumbens). Planta Daninha, v.21, n.1, p.37-44, 2003. Available from: <http://dx.doi. org/10.1590/S0100-83582003000100005>. Accessed: Mar. 22, 2014. doi: $10.1590 / \mathrm{S} 0100-83582003000100005$.

MACIEL, C.D.G.; VELINI, E.D. Simulação do caminhamento da água da chuva e herbicidas em palhadas utilizadas em sistemas de plantio direto. Planta Daninha, v.23, n.3, p.471481, 2005. Available from: <http://dx.doi.org/10.1590/S010083582005000300011>. Accessed: Mar. 22, 2014. doi: 10.1590/ S0100-83582005000300011.

NEGRISOLI, E. et al. Dinâmica de diuron em palha de cana-deaçúcar. In: CONGRESSO BRASILEIRO DA CIÊNCIA DAS PLANTAS DANINHAS, 23., 2002, Gramado, RS. Resumos... Gramado: CBCPD. 2002. p.157.

NEGRISOLI, E. et al. Influência da palha e da simulação de chuva sobre a eficácia da mistura formulada clomazone+hexazinone no controle de plantas daninhas em área de cana-crua. Planta Daninha, v.29, n.169-177, 2011. Available from: <http://dx.doi. org/10.1590/S0100-83582011000100019>. Accessed: Mar. 22, 2014. doi: $10.1590 / \mathrm{S} 0100-83582011000100019$.

RODRIGUES, B.N.; ALMEIDA, F.S. Guia de herbicidas. 6.ed. Londrina: Edição dos autores, 2011. 697p.

RODRIGUES, B.N. et al. Aplicação de trifluralin em préemergência sobre diferentes quantidades de cobertura morta no sistema de plantio direto. In: CONGRESSO BRASILEIRO DA CIÊNCIA DAS PLANTAS DANINHAS, 21., 1997, Caxambu. Resumos... Viçosa: SBCPD, 1997. p.365.

ROSSI, C.V.S. et al. Dinâmica do herbicida metribuzin aplicado sobre palha de cana-de-açúcar (Saccharum 
officinarum). Planta Daninha, v.31, p.223-230, 2013 Available from: $\quad<\mathrm{http} / / / \mathrm{dx}$.doi.org/10.1590/S010083582013000100024>. Accessed: Feb. 14, 2014. doi: 10.1590/S0100-83582013000100024.

SELIM, H.M. et al. Herbicide retention in soil as affected by sugarcane mulch residue. Journal Environmental Quality, v.32, p.1445-1454, 2003. Available from: <http://www.ncbi.nlm.nih gov/pubmed/12931901>. Accessed: Jun. 22, 2014. doi: 10.2134 jeq2003.1445.

TOFOLI, G.R. et al. Dinâmica de atrazine em palha de aveia e cana-de-açúcar. In: CONGRESSO BRASILEIRO DA CIÊNCIA
DAS PLANTAS DANINHAS, 23., 2002, Gramado, RS. Anais... Gramado: SBCPD, 2002. p.158.

YENISH, J.P. et al. Cover crops for herbicide replacement in no-tillage corn (Zea mays L.). Weed Technology, v.10, p.815-821, 1996. Available from: <http://eurekamag.com/ research/002/790/002790545>. Accessed: Jun. 2014. doi: 002790545.

WAUCHOPE, R.D. et al. The SCS/ARA/CES pesticide proper ties database for environmental decision-making. Reviews of Environmental Contamination and Toxicology, v.123, n.1, p.164, 1992. Available from: <http://www.ncbi.nlm.nih.gov/ pubmed/1732992>. Accessed: Feb. 14, 2014. doi: 1732992. 